\title{
Assessment of Cellular Responses after Short- and Long-Term Exposure to Silver Nanoparticles in Human Neuroblastoma (SH-SY5Y) and Astrocytoma (D384) Cells
}

\author{
Teresa Coccini, ${ }^{1,2}$ Luigi Manzo, ${ }^{2,3}$ Vittorio Bellotti, ${ }^{4}$ and Uliana De Simone ${ }^{3}$ \\ ${ }^{1}$ Laboratory of Clinical Toxicology, IRCCS Salvatore Maugeri Foundation, Scientific Institute of Pavia Medical Centre, \\ Via Maugeri 10, 27100 Pavia, Italy \\ ${ }^{2}$ Toxicology Division, Department of Environmental Health, IRCCS Salvatore Maugeri Foundation, \\ Scientific Institute of Pavia Medical Centre, Via Maugeri 10, 27100 Pavia, Italy \\ ${ }^{3}$ Toxicology Unit, Department of Clinical Surgical, Diagnostic and Pediatric Sciences, Faculty of Medicine and Surgery, \\ University of Pavia, Via Maugeri 10, 27100 Pavia, Italy \\ ${ }^{4}$ Department of Molecular Medicine, Institute of Biochemistry, University of Pavia, Via Forlanini 6, 27100 Pavia, Italy
}

Correspondence should be addressed to Teresa Coccini; teresa.coccini@fsm.it

Received 18 November 2013; Accepted 29 December 2013; Published 13 February 2014

Academic Editors: B. Soto-Blanco, A. Takagi, and D. N. Tripathi

Copyright (C) 2014 Teresa Coccini et al. This is an open access article distributed under the Creative Commons Attribution License, which permits unrestricted use, distribution, and reproduction in any medium, provided the original work is properly cited.

\begin{abstract}
Silver nanoparticle (AgNP, $20 \mathrm{~nm}$ ) neurotoxicity was evaluated by an integrated in vitro testing protocol employing human cerebral (SH-SY5Y and D384) cell lines. Cellular response after short-term $(4-48 \mathrm{~h}, 1-100 \mu \mathrm{g} / \mathrm{ml}$ ) and prolonged exposure (up to 10 days, $0.5-50 \mu \mathrm{g} / \mathrm{ml}$ ) to AgNP was assessed by MTT, calcein-AM/PI, clonogenic tests. Pulmonary A549 cells were employed for data comparison along with silver nitrate as metal ionic form. Short-term data: (i) AgNP produced dose- and time-dependent mitochondrial metabolism changes and cell membrane damage (effects starting at $25 \mu \mathrm{g} / \mathrm{ml}$ after $4 \mathrm{~h}$ : EC $\mathrm{EC}_{50 \mathrm{~s}}$ were $40.7 \pm 2.0$ and $49.5 \pm 2.1 \mu \mathrm{g} / \mathrm{ml}$ for SH-SY5Y and D384, respectively). A549 were less vulnerable; (ii) AgNP doses of $\leq 18 \mu \mathrm{g} / \mathrm{ml}$ were noncytotoxic; (iii) $\mathrm{AgNO}_{3}$ induced more pronounced effects compared to AgNP on cerebral cells. Long-term data: (i) low AgNP doses ( $\left.\leq 1 \mu \mathrm{g} / \mathrm{ml}\right)$ compromised proliferative capacity of all cell types (cell sensibility: SHSY5Y > A549 > D384). Colony number decrease in SH-SY5Y and D384 was $50 \%$ and $25 \%$, respectively, at $1 \mu \mathrm{g} / \mathrm{ml}$, and lower dose $(0.5 \mu \mathrm{g} / \mathrm{ml})$ was significantly effective towards SH-SY5Y and pulmonary cells; (ii) cell proliferation activity was more affected by $\mathrm{AgNO}_{3}$ than AgNPs. In summary, AgNP-induced cytotoxic effects after short-term and prolonged exposure (even at low doses) were evidenced regardless of cell model types.
\end{abstract}

\section{Introduction}

Although there is great uncertainty over the potential risks of nanotechnology products, their commercialization continues to grow albeit under conditions of uncertainty regarding the implications for health and the environment [1]. Currently, the majority of nanotechnology-enabled consumer products are based on nanoscale silver [2]. Nanosilver or nanoparticle sized silver (AgNP) provides a greater surface area of silver and theoretically a more efficacious product with higher activity than its bulk counterpart [3]. The many possibilities offered by AgNP in medical application (due to its antibacterial properties and as biosensors and imaging contrast agents), but also in the growth market of consumer products (e.g., for disinfection of water, as well as coating of surfaces in contact with human skin, textiles, or food) have raised much scientific interest and concern in the last decade [4]. The sophistication of this new nanotechnology and its proliferation (largely uncontrolled) raises new questions of health and environmental impact. One of the relevant questions regarding the safety of nanosilver in consumer products that still needs to be clarified is whether the toxic potential of nanosilver is identical to "classical" silver [5]. The point is that silver is an old problem and nanosilver is a new 
challenge. The scope of the new challenge is not yet clear because it is uncertain how much nanosilver is now used as an antimicrobial in commercial and consumer products and because new uses are likely to be discovered in the future. Actually, AgNP regulation is still undergoing major changes to encompass environmental, health, and safety issues [6]. The uncertainty of the safety may be compounded by lack of toxicological data and lifecycle studies of acceptable environmental exposure limits to nanosilver compounds.

Although a lot of work has been done as well as many reports and reviews have been published on nanosilver [7], few studies have been performed to address AgNP exposure and central nervous system (CNS) toxicity.

Since the extent of human exposure to AgNPs and their likelihood internalization has strongly increased during the last years, the internalized AgNPs may finally also reach the brain and encounter brain cells. Recent studies have drawn attention towards potential neurotoxic effects of AgNPs. It is well known that the CNS is highly sensitive to metals including silver $[8,9]$ which is known to avidly bind to the cells of nervous system. Moreover its biological halflife in the CNS is longer than that in other organs causing neurotoxic damage, consequences, and risks to the brain following prolonged exposure [10]. Decreased activity in mice and concomitant granular silver deposits, especially in brain areas involved in motor control, was found in mice orally exposed to $\mathrm{AgNO}_{3}$ for four months [11]. With respect to AgNPs, there is evidence, although little, indicating that AgNP itself can impact the CNS. AgNPs can cross and disrupt the rat blood-brain barrier $[12,13]$ and even aggravate heat stress-induced cognitive deficits, edema formation, and brain pathology [14]. In vivo effects of AgNPs include edema [13] and changes in the brain mRNA levels of genes linked to increased oxidative stress [15]. In vivo studies have also indicated that AgNPs accumulate in the rodent olfactory bulb and brain after inhalation; thus, by retrograde transport, AgNPs might get access to selective regions of the CNS inducing brain inflammation and neurotoxicity [16].

Currently, few are also the data regarding the in vitro neurotoxicity of AgNPs on human nervous system cells [17, 18]. The majority of toxicological data published on AgNPs derives from in vitro studies which typically have used rat neuronal-like cell lines, mostly PC-12 cells [19-23] or primary neural cells obtained from rodents [24-27]. Disruption and inflammation have also been demonstrated in in vitro bloodbrain barrier (BBB) models (from rat) following incubation with AgNPs [28, 29].

Standard toxicological tests are still needed to be performed to assess the risk of AgNPs. For example, biosafety of ENMs (man-made particles with any external dimension between 1 and $100 \mathrm{~nm}$ ) could be evaluated by tests examining general toxicity, target organ toxicity, and biocompatibility in line with regulatory requirements, applying alternative test methods (e.g., in vitro cellular assays) limiting the use of lab animals in toxicological research [30-32], to identify molecular endpoints and multiple toxicity pathways. In vitro studies can obtain toxicological data relevant to design appropriate exposure concentrations and define critical health endpoints to be monitored in vivo.
The present investigation proposes an integrated in vitro testing protocol for the screening of AgNP neurotoxicity using representative human cerebral cell lines and a battery of cytotoxicity tests to simulate both short- and long-term exposure. In particular, increasing concentrations of critical doses of an AgNP model (20 nm) have been evaluated:

(i) in brain cells, namely, human astrocytoma D384 and neuroblastoma SH-SY5Y cell lines, as well as in human lung epithelial cells (A549), for data comparison, since some cytotoxicity results in A549 are already available such as those related to AgNP acute exposure [33, 34];

(ii) after short-term exposure (4-24-48 h) at doses ranging from 1 to $100 \mu \mathrm{g} / \mathrm{mL}$ and prolonged (up to 10 days) exposure at low doses ranging from 0.5 to $50 \mu \mathrm{g} / \mathrm{mL}$.

The cellular biological responses after AgNP treatment included the evaluation of mitochondrial function (using MTT test), membrane integrity and cellular morphology (by calcein-AM/propidium iodide staining), cellular growth, and proliferation (clonogenic tests for sublethal effects).

Silver nitrate $\left(\mathrm{AgNO}_{3}\right)$ has been concomitantly tested, in all experiment types, as positive control for silver toxicity caused by metal ionic form added as soluble salt.

The choice of AgNP size and concentrations was based on previously reports indicating than AgNPs $(20 \mathrm{~nm})$ possessed high cytotoxic properties with respect to permeating and damaging cerebral microvascular structures, as compared with larger particles (40 and $80 \mathrm{~nm}$ ) [29]. Smaller nanoparticles $(20 \mathrm{~nm})$ have also been shown to induce higher levels of cellular oxidative damage [26]. Experiments conducted with 20-40 nm AgNPs and using concentrations ranging from 1 to $100 \mu \mathrm{g} / \mathrm{mL}$ to examine the potential hazardous effects of AgNPs with rat primary neuronal cells have found that AgNPs affect voltage-gated sodium and potassium channels, disturb neuronal calcium homeostasis, and reduce dopamine concentration [24-26].

Based on these studies, we pursued to identify the effects not only after AgNP acute exposure but also after continuous exposure to AgNPs (20 nm) at low doses of $0.5,1,10,25$, and $50 \mu \mathrm{g} / \mathrm{mL}$ on human CNS cell viability, metabolic activity, membrane integrity, and cell morphology.

\section{Materials and Methods}

2.1. Chemicals. All cell culture reagents, culture medium, chemicals, and silver nitrate $\left(\mathrm{AgNO}_{3}\right)$ were purchased from Sigma-Aldrich (Milan, Italy).

\subsection{Physicochemical Characteristics of Silver Nanoparticles} (AgNPs). AgNPs were supplied by Colorobbia (Colorobbia S.p.A., Vinci, Italy), series PARNASOS NAMA 391103 F011\%. The characteristics of AgNP 1\% in water with the appearance of brown colour were $1 \mathrm{~g} / \mathrm{cm}^{3}$ density, $3 \mathrm{mPa} / \mathrm{sec}$ viscosity $\left(25^{\circ} \mathrm{C}\right),<0.50 \mathrm{PdI}, 6.5 \mathrm{pH}$, and $20 \mathrm{~nm}$ nominal hydrodynamic size diameter $(20-100 \mathrm{~nm}$ size distribution determined by Dynamic light scattering by Malvern Instruments Ltd.). 


\subsection{In Vitro Studies}

2.3.1. Cell Line and Cell Culture. Human neuroblastoma (SH-SY5Y cell line purchased from ECACC, Sigma-Aldrich, Milan, Italy), human astrocytoma cells (D384 clonal cell line was established from [35]), and human lung epithelial cells (A549 cell line purchased from ECACC, Sigma-Aldrich, Milan, Italy) were used for in vitro studies of the AgNP toxicity after short- (4-48h) and long-term (7-10 days) exposure.

SH-SY5Y cells were cultured in Eagle's minimum essential medium and Ham's F12 (1:1) with 15\% fetal bovine serum (FBS), $2 \mathrm{mM} \mathrm{L}$-glutamine, $50 \mathrm{IU} / \mathrm{mL}$ penicillin, and $50 \mu \mathrm{g} / \mathrm{mL}$ streptomycin.

D384 cells were cultured in Dulbecco's modified Eagle medium (DMEM) supplemented with $10 \% \mathrm{FBS}, 2 \mathrm{mM} \mathrm{L-}$ glutamine, $50 \mathrm{IU} / \mathrm{mL}$ penicillin, $50 \mu \mathrm{g} / \mathrm{mL}$ streptomycin, and $1 \%$ sodium pyruvate. A549 cells were cultured in DMEM supplemented with $10 \% \mathrm{FBS}, 2 \mathrm{mM}$ L-glutamine, $50 \mathrm{IU} / \mathrm{mL}$ penicillin, and $50 \mu \mathrm{g} / \mathrm{mL}$ streptomycin. Cells were maintained at $37^{\circ} \mathrm{C}$ in a humidified atmosphere ( $95 \%$ air $\left./ 5 \% \mathrm{CO}_{2}\right)$.

Stock solutions were prepared by dissolving AgNPs in culture medium; cells were exposed to concentrations ranging from 0.5 to $100 \mu \mathrm{g} / \mathrm{mL}$. For comparison, equivalent amount of $\mathrm{AgNO}_{3}$ was tested. Fresh solutions of test materials were prepared shortly before each experiment.

\subsection{Cytotoxicity Study: Short-Term Exposure (4-48 h)}

2.4.1. Mitochondrial Function (MTT Assay) and Membrane Integrity (Calcein-AM/Propidium Iodide Staining). The cellular viability, membrane integrity, and cell morphology of SH-SY5Y, D384, and A549 cells treated with AgNPs or $\mathrm{AgNO}_{3}$ were determined using two colorimetric methodologies: MTT assay enables accurate, straightforward quantification of changes in metabolic activities (i.e., mitochondrial function) and calcein-AM/propidium iodide (PI) staining allows qualitative evaluation on membrane integrity and cell morphology and quantitative evaluation on cell viability (cell live/cell death).

Cells were seeded in 96-well plates at density of $1 \times 10^{4}$ cells/well in complete medium. After $24 \mathrm{~h}$ of cell attachment, the cells were exposed to $\mathrm{AgNPs}$ or $\mathrm{AgNO}_{3}$ at final concentrations between 1 and $100 \mu \mathrm{g} / \mathrm{mL}$ for 4,24 , and $48 \mathrm{~h}$ at $37^{\circ} \mathrm{C}$.

At the end of the incubation period, the mitochondrial function was assessed by $0.5 \mathrm{mg} / \mathrm{mL}$ MTT (3-(4,5dimethylthiazol-2-yl)-2,5-diphenyltetrazolium bromide) for $3 \mathrm{~h}$ at $37^{\circ} \mathrm{C}$ and was quantified spectrophotometrically at $550 \mathrm{~nm}$ in Bio-Rad microplate reader. Data were expressed as a percentage of control (untreated cells).

The membrane integrity and cell morphology were evaluated by the coincubation of the double staining: $2 \mu \mathrm{M}$ calcein$\mathrm{AM}$ and $2.5 \mu \mathrm{g} / \mathrm{mL}$ PI for $10 \mathrm{~min}$ at $37^{\circ} \mathrm{C}$. Cells were examined under a Zeiss Axiovert 25 fluorescence microscope combined with digital camera (Canon powershot G8). The fluorescence images were taken using 32x objective lens with an excitation wavelength of 400, 495, and $570 \mathrm{~nm}$, beamsplitter wavelength of 410,505 , and $585 \mathrm{~nm}$, and an emission wavelength of 460,530 , and $610 \mathrm{~nm}$. Viability was expressed as \% of cells that retained calcein (green fluorescence) compared to the total cells counted (calcein-positive plus PI-positive (red fluorescence)).

\subsection{Cytotoxicity Study: Long-Term Exposure (10 Days)}

2.5.1. Clonogenic Assay. The procedure for clonogenic assay with the presently used cell types was previously described [36]. Briefly, cells were seeded in six-well plates at density of 300 cells/well for SH-SY5Y cells, 50 cells/well for D384 cells, and 400 cells/well for A549 cells, each well containing $2 \mathrm{~mL}$ of cell culture medium. After attachment (about $20 \mathrm{~h}$ for SH-SY5Y, $4 \mathrm{~h}$ for D384 cells, and $14 \mathrm{~h}$ for A549 cells; each time was shorter than the population doubling time 48, 9, and $24 \mathrm{~h}$, resp.) the cells were washed with $2 \mathrm{~mL}$ PBS and treated with $2 \mathrm{~mL}$ AgNPs (final concentration ranging from 0.5 to $50 \mu \mathrm{g} / \mathrm{mL}$ in cell culture medium) or $\mathrm{AgNO}_{3}$, over a time period required to form colonies (about 10 days for $\mathrm{SH}$ SY5Y and A549 cells and 7 days for D384 cells). A colony being defined as at least 50 clones of one cell. At the end of the treatment, the medium was removed and the colonies were fixed, stained with hematoxylin, and then were manually counted for the evaluation of cell survival after AgNP and $\mathrm{AgNO}_{3}$ treatments. The minimum size of colony was considered to be 50 cells/colony. The colonies were examined under Zeiss Axiovert 25 microscope combined with a digital camera (Canon powershot G8). Digital photographs were taken from each well using $2.5 \mathrm{x}$ objective lens. The number of colonies that arose after treatment was expressed in terms of plating efficiency (PE). PE was calculated by dividing the number of colonies formed by the number of cells plated per 100 .

2.6. Statistics. Data from short-term exposure were obtained from three independent experiments, each experiment was carried out in six replicates. Data from long-term exposure were obtained from two independent experiments and each experiment was carried out in three replicates. Results are expressed as mean \pm SD. Statistical analysis was performed by one-way ANOVA followed by Tukey's test (for each time point). A value of $P<0.05$ was considered statistically significant.

Cytotoxicity data by MTT was fitted to an exponential growth model in order to calculate the $50 \%$ effective concentration $\left(\mathrm{EC}_{50}\right)$. This analysis was performed using the REGTOX-EV7.xls curve fitting add-in macro for Microsoft Excel ( http://www.normalesup.org/ vindimian/macro/REGTOX_EV7.0.6.xls).

\section{Results}

3.1. Cytotoxic Activity of AgNPs Compared to $\mathrm{AgNO}_{3}$ in Human Nervous (SH-SY5Y and D384 Cell Lines) and Pulmonary Cells (A549 Cell Line). In vitro cytotoxicity due to the short (4-24-48h) and prolonged (7 or 10 days) exposure of SH-SY5Y, D384, and A549 cells to increasing concentrations of AgNPs (from 0.5 to $100 \mu \mathrm{g} / \mathrm{mL}$ ) and $\mathrm{AgNO}_{3}$ is reported and compared. Mitochondrial function, membrane integrity, and cell morphology were considered as endpoints of acute 


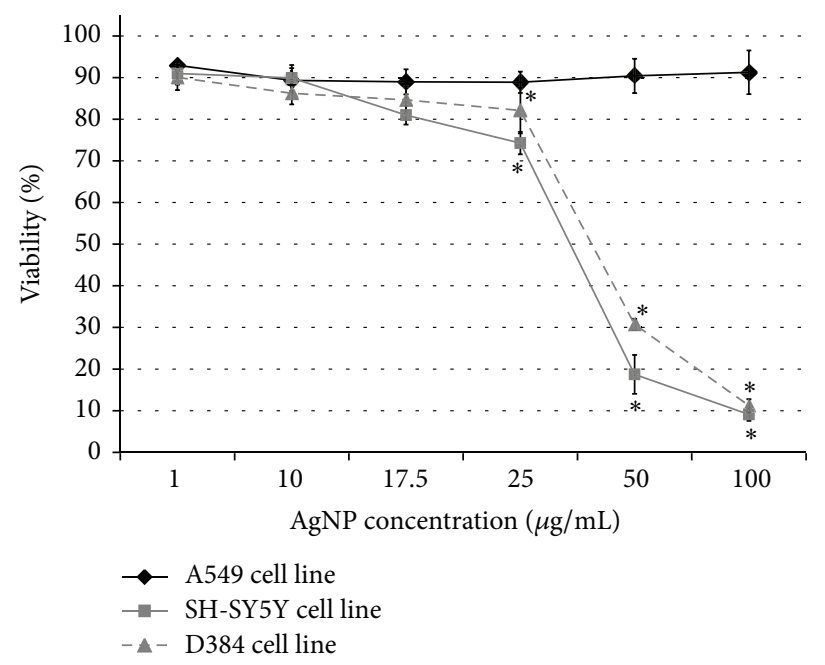

(a)

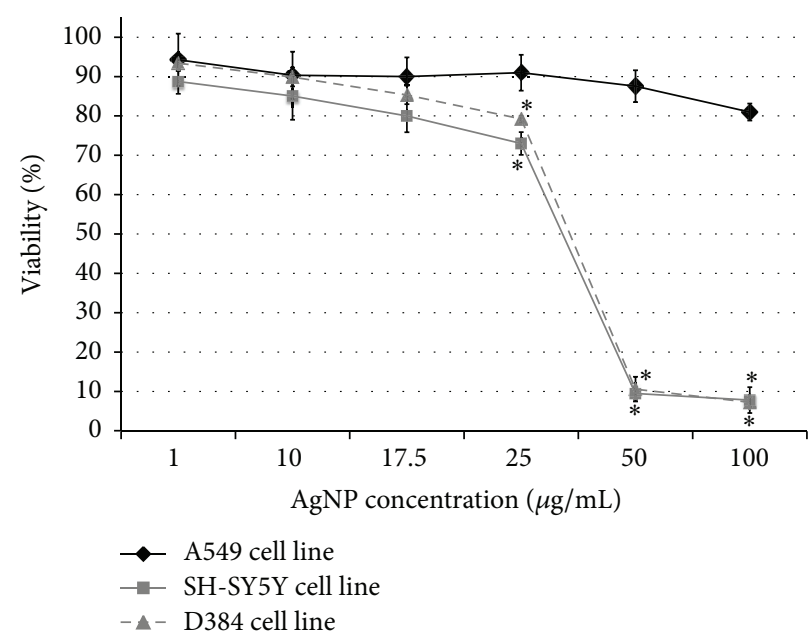

(b)

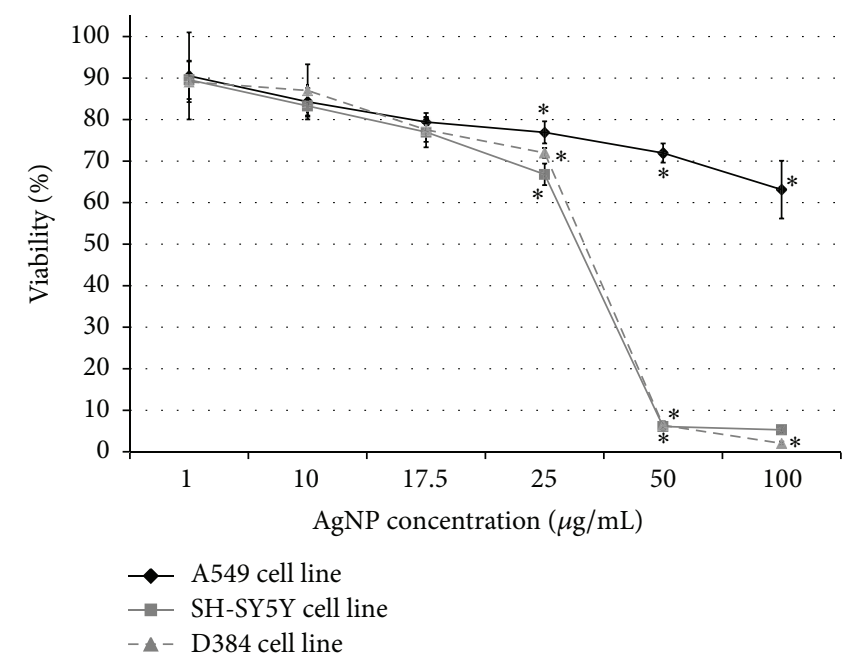

(c)

FIGURE 1: Mitochondrial function evaluation by MTT assay in SH-SY5Y, D384, and 549 cell lines. Evaluation of mitochondrial function in

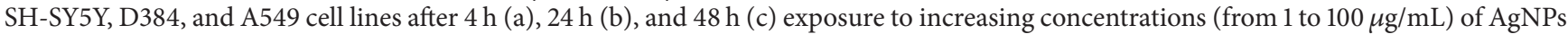
showed dose- and time-dependent changes in mitochondrial metabolism on both cerebral cell lines starting at the dose of $25 \mu \mathrm{g} / \mathrm{mL}$ and already after $4 \mathrm{~h}$ exposure. Pulmonary cells (A549) were less susceptible to AgNP exposure, showing a reduction of cell viability after $48 \mathrm{~h}$ exposure at the higher doses of AgNPs. ${ }^{*}$ Different from control in each cell line $P<0.05$, Statistical analysis by ANOVA followed by Tukey's test. Error bars indicate S.D.

exposure, while the capacity to form colonies was considered as endpoint of chronic exposure.

\subsection{Cytotoxicity Results after Short-Term Exposure (4-48 h)}

3.2.1. Mitochondrial Function. MTT Assay. Data of mitochondrial function, evaluated by MTT after 4, 24, and $48 \mathrm{~h}$ of exposure to increasing concentrations of AgNPs (1$100 \mu \mathrm{g} / \mathrm{mL}$ ) and expressed as percentage of the viability of control, are presented in Figure 1. AgNPs induced dosedependent cytotoxic effects on both SH-SY5Y and D384 cells; there was a strong cell viability decrease already after $4 \mathrm{~h}$ exposure (Figure 1(a)); loss of cell viability was about 25$85 \%$ at doses ranging from 25 to $100 \mu \mathrm{g} / \mathrm{mL}$, and no effect was observed from 1 to $17.5 \mu \mathrm{g} / \mathrm{mL}$. The cytotoxic effect of AgNPs for both cerebral cell types was shown to be more pronounced after 24 and $48 \mathrm{~h}$ exposure as indicated by about $100 \%$ reduction of cell viability at the highest tested doses $(50-100 \mu \mathrm{g} / \mathrm{mL}$ ) (Figures 1(b) and 1(c)). A549 cells were less susceptible than cerebral cells, showing about $35 \%$ cell viability reduction after $48 \mathrm{~h}$ exposure to the highest tested dose of $100 \mu \mathrm{g} / \mathrm{mL}$ AgNPs (Figure 1(c)).

In addition, MTT data were used to calculate $\mathrm{EC}_{50}(50 \%$ effective concentration) values and were used to compare the toxicity rank of AgNPs on SH-SY5Y, D384, and A549 cell 
lines. As illustrated in Table 1, both the $\mathrm{EC}_{50 \text { s }}$ of SH-SY5Y and D384 were observed to be dependent on the dose used and time period of exposure, while the $\mathrm{EC}_{50}$ of A549 was significantly greater than the highest dose of AgNP tested, indicating that A549 cells were less susceptible to AgNP treatment compared to SHSY5Y and D384 cells.

AgNP versus $\mathrm{AgNO}_{3}$ Comparison. Using $\mathrm{AgNO}_{3}$ at 1 and $10 \mu \mathrm{g} / \mathrm{mL}$, the noncytotoxic doses for AgNPs, a strong toxic effect was observed especially at $10 \mu \mathrm{g} / \mathrm{mL}$ in both cerebral cell lines (SH-SY5Y and D384 cells) and for each considered time point (i.e., 4, 24, and $48 \mathrm{~h}$ ), while in A549, the $\mathrm{AgNO}_{3}$ effect was less pronounced (Figures 2(a), 2(b), and 2(c)).

Specifically, up to about $18 \mu \mathrm{g} / \mathrm{mL}$ AgNPs did not produce any cytotoxic effect within $48 \mathrm{~h}$ in all considered cell types differently from $\mathrm{AgNO}_{3}$ that showed to be very toxic (especially at $10 \mu \mathrm{g} / \mathrm{mL}$ ) in the cerebral cell lines and weakly effective in A549.

\subsubsection{Membrane Integrity: Calcein-AM/PI Staining. Mem-} brane integrity and cell morphology were evaluated by calcein-AM/PI staining after 4, 24, and $48 \mathrm{~h}$ exposure to increasing concentrations of AgNPs (1-100 $\mu \mathrm{g} / \mathrm{mL})$. Figure 3 describes a panel of representative and randomly selected microscopic fields of SH-SY5Y, D384, and A549 cells treated with AgNPs. Effect on cell viability was also confirmed using calcein-AM/PI double staining for all cell types.

The green fluorescence of SH-SY5Y and D384 cells after $4 \mathrm{~h}$ exposure was uniformly diffused in cell cytoplasm (indicating the maintained membrane integrity) at doses ranging from 1 to $25 \mu \mathrm{g} / \mathrm{mL}$ and cell morphology was not altered with respect to control $(1-10 \mu \mathrm{g} / \mathrm{mL}$ data are shown in the Supplementary additional file 1, available online at http://dx.doi.org/10.1155/2014/259765; it reports membrane integrity evaluation by Calcein-AM/PI staining of SH-SY5Y, D384, or A549 cells after 4, 24, and $48 \mathrm{~h}$ exposure to increasing concentrations $(1-100 \mu \mathrm{g} / \mathrm{ml})$ of AgNPs. Figure 3 shows $25-100 \mu \mathrm{g} / \mathrm{mL}$ ), while a strong decrease in cell viability for both cell lines was observed as evidenced by the presence of numerous red coloured cells (indicating damage to the cell membrane) at the highest doses $(50-100 \mu \mathrm{g} / \mathrm{mL})$ (Figure 3).

After 24 and $48 \mathrm{~h}$, the cytotoxic effect of AgNP was exacerbated as even shown by semiquantitative analysis (Table 2) of selected microscopic fields, in terms of cell counts and expressed as percentage of live cells (green fluorescence). SH-SY5Y cells were more sensitive towards AgNPs since the cell loss was evident at the dose of $25 \mu \mathrm{g} / \mathrm{mL}$ (Figure 3; Table 2).

Fluorescence images of A549 cells (Figure 3) showed uniformly diffused green fluorescence and normal cell morphology for all treatment concentrations $(1-100 \mu \mathrm{g} / \mathrm{mL})$ and at each time point $(4,24$, and $48 \mathrm{~h})$ when compared to control. Semiquantitative analysis on A549 cells with increasing concentrations of AgNPs $(1-100 \mu \mathrm{g} / \mathrm{mL})$ showed a slight decrease of cell viability (about 15-20\%) after $48 \mathrm{~h}$ exposure only (Table 2).
TABLE 1: $\mathrm{EC}_{50}$ after 4,24 , and $48 \mathrm{~h}$ exposure to AgNPs $(1-100 \mu \mathrm{g} / \mathrm{mL})$. Effective concentrations causing $50 \%\left(\mathrm{EC}_{50}\right.$ values, $\left.\mu \mathrm{g} / \mathrm{mL}\right)$ loss of cell viability (evaluated by MTT test) for SH-SY5Y, D384, and A549 cell lines following exposure to increasing concentrations of AgNP $(0-100 \mu \mathrm{g} / \mathrm{mL})$.

\begin{tabular}{lccc}
\hline Cell type & \multicolumn{3}{c}{$\mathrm{EC}_{50}(\mu \mathrm{g} / \mathrm{mL})$} \\
& $\begin{array}{c}24 \mathrm{~h} \\
\text { exposure }\end{array}$ & $\begin{array}{c}48 \mathrm{~h} \\
\text { exposure }\end{array}$ \\
\hline SH-SY5Y & $40.71 \pm 2.00$ & $30.73 \pm 3.20$ & $28.38 \pm 3.00$ \\
D384 & $49.49 \pm 2.10$ & $33.41 \pm 4.00$ & $30.21 \pm 3.40$ \\
& No cytotoxic & No cytotoxic & Cytotoxic effects starting \\
A549 & effects & $100 \mu \mathrm{g} / \mathrm{mL}$ (about \\
& & $65 \%$ viability)
\end{tabular}

TABLE 2: Semiquantitative cell live analysis after 4-48 h exposure to increasing concentrations of AgNPs $(1-100 \mu \mathrm{g} / \mathrm{mL})$. Semiquantitative analysis of selected microscopic fields of SH-SY5Y, D384, and A549 cells after 4, 24, and $48 \mathrm{~h}$ exposure to increasing concentrations of AgNPs $(1-100 \mu \mathrm{g} / \mathrm{mL})$, in terms of cell counts and expressed as percentage of live cells (mean \pm S.D).

\begin{tabular}{|c|c|c|c|}
\hline \multirow{2}{*}{$\operatorname{AgNP}(\mu \mathrm{g} / \mathrm{mL})$} & \multicolumn{3}{|c|}{ Live cells (\%) } \\
\hline & $4 \mathrm{~h}$ exposure & $24 \mathrm{~h}$ exposure & $48 \mathrm{~h}$ exposure \\
\hline \multicolumn{4}{|c|}{ SH-SY5Y cells } \\
\hline 1 & 100 & 100 & 100 \\
\hline 10 & 100 & 100 & 100 \\
\hline 25 & 100 & $35.5 \pm 9.46^{*}$ & $21 \pm 5.69^{*}$ \\
\hline 50 & $0^{*}$ & $0^{*}$ & $0^{*}$ \\
\hline 100 & $0^{*}$ & $0^{*}$ & $0^{*}$ \\
\hline \multicolumn{4}{|c|}{ D384 cells } \\
\hline 1 & 100 & 100 & 100 \\
\hline 10 & 100 & 100 & 100 \\
\hline 25 & 100 & 100 & 100 \\
\hline 50 & $59.67 \pm 12.40^{*}$ & $41.67 \pm 5.11^{*}$ & $6.17 \pm 3.20^{*}$ \\
\hline 100 & $4.00 \pm 6.20^{*}$ & $0^{*}$ & $0^{*}$ \\
\hline \multicolumn{4}{|c|}{ A549 cells } \\
\hline 1 & 100 & 100 & $84.66 \pm 4.08$ \\
\hline 10 & 100 & 100 & $82.00 \pm 2.45$ \\
\hline 25 & 100 & 100 & $81.66 \pm 2.87$ \\
\hline 50 & 100 & 100 & $79.50 \pm 2.88$ \\
\hline 100 & 100 & 100 & $80.83 \pm 2.40$ \\
\hline
\end{tabular}

Mean of 6 images for each cell type and each dose of AgNPs. ${ }^{*}$ Statistical analysis by ANOVA with Tukey's test compared to its control $(P<0.05)$.

AgNP versus $\mathrm{AgNO}_{3}$ Comparison. Cytotoxicity induced by $\mathrm{AgNO}_{3}$ and evaluated with calcein-AM/PI still shows to be pronounced at 1 and $10 \mu \mathrm{g} / \mathrm{mL}$ (noncytotoxic doses for AgNPs) for both SH-SY5Y and D384 cells and at each considered time point (i.e., 4, 24, and $48 \mathrm{~h}$ ), while, in A549, both $\mathrm{AgNO}_{3}$ and $\mathrm{AgNPs}$ produced similar cytotoxic effect for both 1 and $10 \mu \mathrm{g} / \mathrm{mL}$ doses (Figures 2(d), 2(e), and 2(f)). 


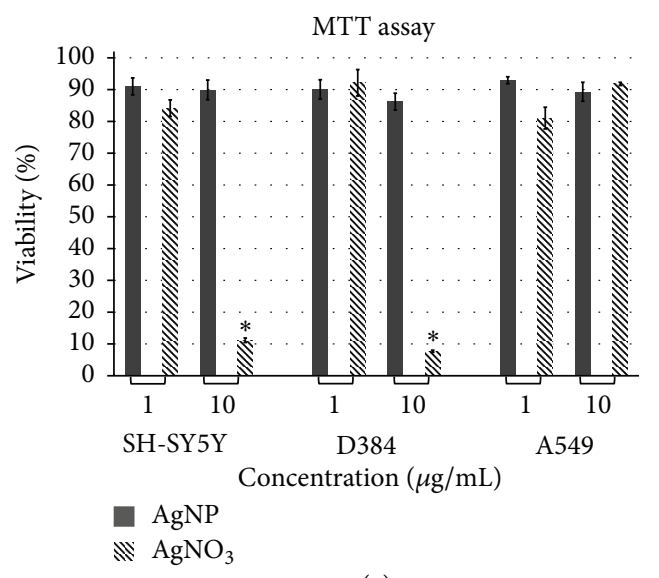

(a)

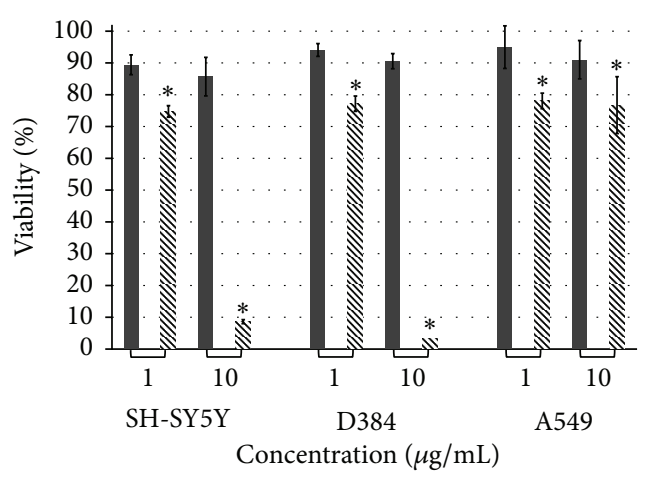

(b)

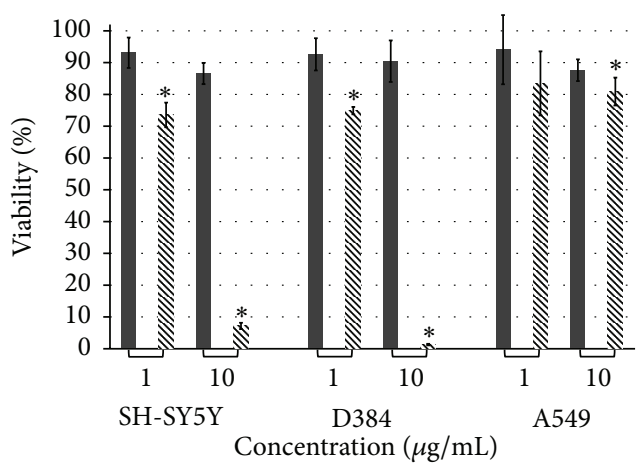

(c)

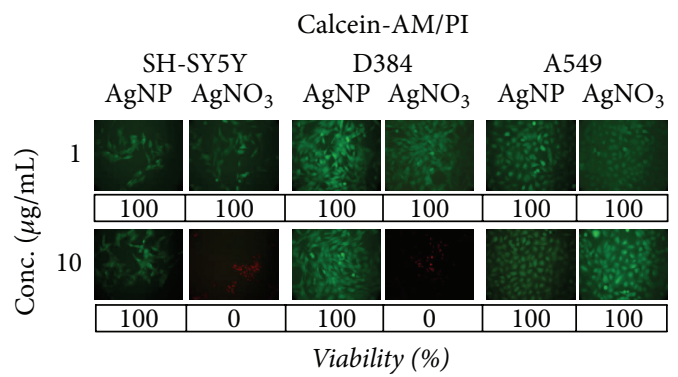

(d)

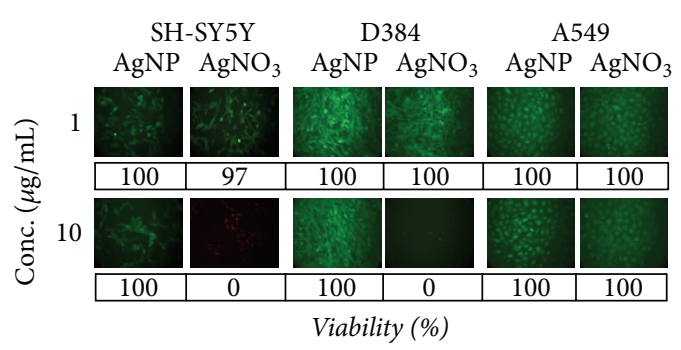

(e)

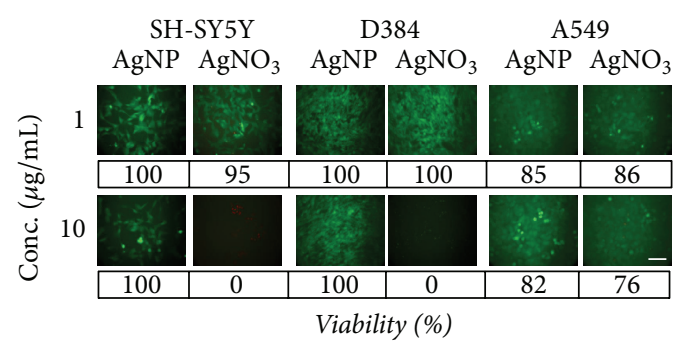

(f)

Figure 2: Data comparisons between AgNPs and $\mathrm{AgNO}_{3}$ in SH-SY5Y, D384 and A549 cell lines. Panels (a), (b), and (c) show mitochondrial function evaluation by MTT assay after $4 \mathrm{~h}, 24 \mathrm{~h}$ and $48 \mathrm{~h}$ exposure to 1 and $10 \mu \mathrm{g} / \mathrm{ml}$ of AgNPs and $\mathrm{AgNO}_{3} .{ }^{*}$ Different from control in each cell line $P<0.05$, statistical analysis by ANOVA followed by Tukey's test. Error bars indicate S.D. Panels (d), (e), and (f) show membrane integrity by calcein-AM/Propidium Iodide staining after $4 \mathrm{~h}, 24 \mathrm{~h}$ and $48 \mathrm{~h}$ exposure to 1 and $10 \mu \mathrm{g} / \mathrm{ml}$ of AgNPs and $\mathrm{AgNO}_{3}$; scale bar $100 \mu \mathrm{m}$. $\mathrm{AgNO}_{3}$ produced a more pronounced cytotoxic effect to that caused by comparable amount of AgNPs on cerebral cell lines. In A549 cells, similar low cytotoxic profile was observed after both treatment types (AgNPs and $\mathrm{AgNO}_{3}$ ).

\subsection{Cytotoxicity Results after Long-Term Exposure (10 Days)}

3.3.1. Clonogenic Assay. To determine whether the prolonged exposure (up to 10 days) to increasing AgNP concentrations $(0.5-50 \mu \mathrm{g} / \mathrm{mL})$ might cause adverse effects, the proliferation ability and colony forming capacity of SH-SY5Y, D384, and A549 cells were evaluated. Figure 4 shows representative images of randomly selected microscopic fields of the different cell types.

Colonies of SH-SY5Y and D384 treated with increasing concentrations of AgNPs $(0.5-25 \mu \mathrm{g} / \mathrm{mL})$ and colonies of A549 treated with AgNPs $(0.5-50 \mu \mathrm{g} / \mathrm{mL})$ showed dosedependent reductions on size and colony number, as well as changes in colony morphology compared to each respective 


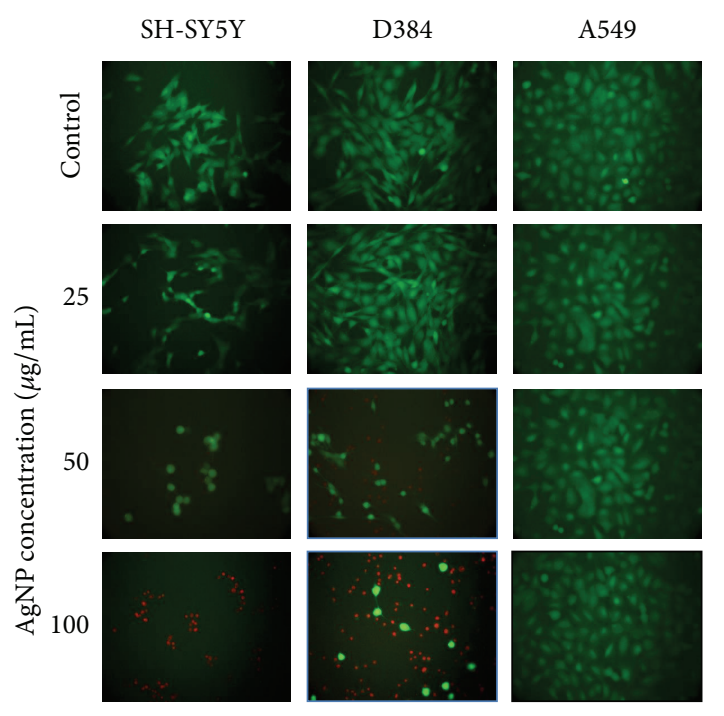

(a)

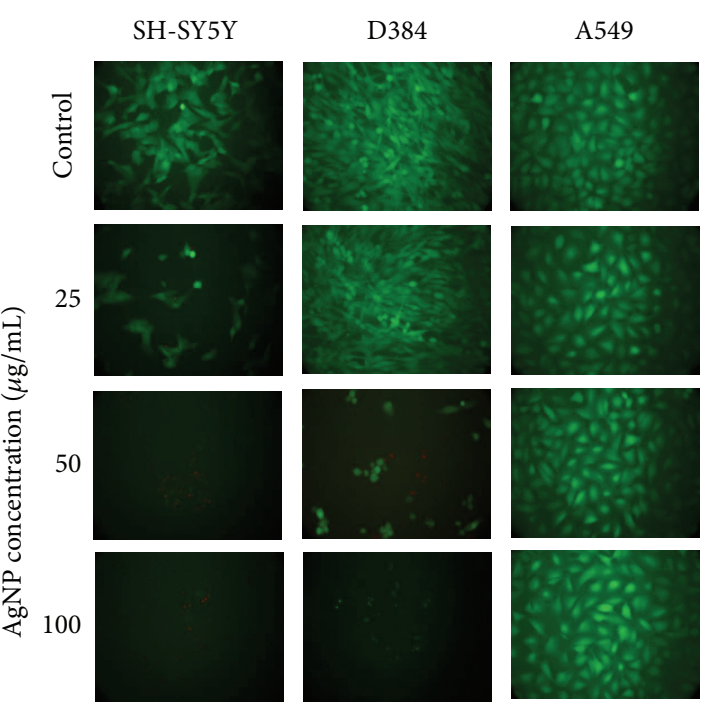

(b)

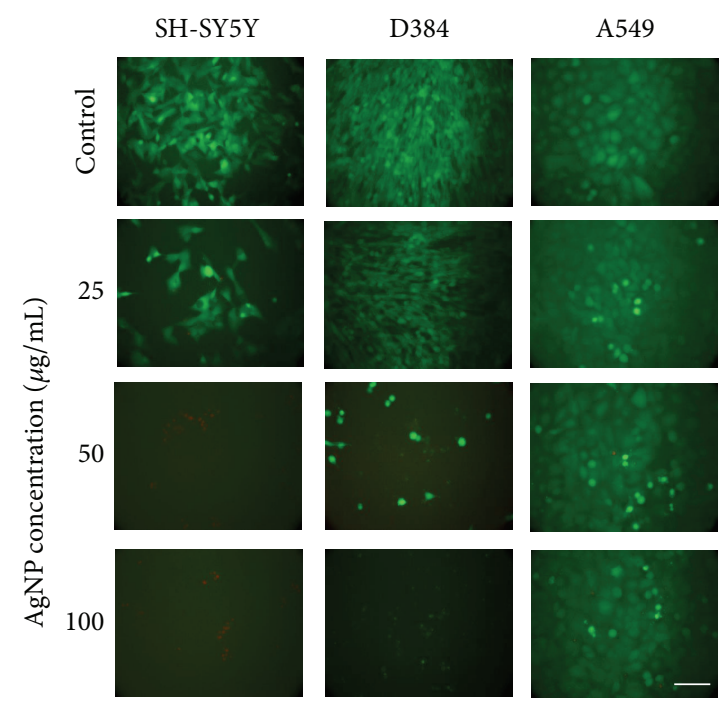

(c)

FiguRE 3: Membrane integrity evaluation. Representative images of randomly selected microscopic fields of cells (SH-SY5Y, D384, or A549) stained with calcein-AM/propidium iodide after 4 (a), 24 (b), and 48 (c) h exposure to increasing concentrations (25-100 $\mu \mathrm{g} / \mathrm{mL})$ of AgNPs. Green fluorescence patterns and the cellular morphology were similar to the controls. A strong decrease in cell viability for both cerebral cell lines was observed as evidenced by the presence of numerous red coloured cells (indicating damage to the cell membrane) at the highest doses (50-100 $\mu \mathrm{g} / \mathrm{mL})$. After 24 and $48 \mathrm{~h}$, the cytotoxic effect of AgNPs was exacerbated. SH-SY5Y cells were the most sensitive towards AgNP since the cell loss was evident at the dose of $25 \mu \mathrm{g} / \mathrm{mL}$, whereas pulmonary cells (A549) were less susceptible to AgNP exposure compared to cerebral cell types, showing a slight decrease of cell viability after $48 \mathrm{~h}$ exposure only (scale bar is $100 \mu \mathrm{m}$ ).

control (Figures 4(a), 4(b), and 4(c)). Semiquantitative analysis showed a strong reduction (about 90\%) of colony number of D384 at the highest treatment dose of $25 \mu \mathrm{g} / \mathrm{mL}$, and SHSY5Y cells were totally inhibited (Figure 4(d)). AgNP effect was more pronounced on SH-SY5Y compared to D384: 50\% versus $25 \%$ decrease in colony number for SH-SY5Y and D384, respectively, at $1 \mu \mathrm{g} / \mathrm{mL}$, and $45 \%$ decrease was already observed in SH-SY5Y at the lowest tested dose of $0.5 \mu \mathrm{g} / \mathrm{mL}$.

Different from short-term exposure data, A549 cells showed to be sensitive towards AgNP exposure already after applying the lowest dose of $0.5 \mu \mathrm{g} / \mathrm{mL}$. Moreover, $75 \%$ decrease in colony number was observed at the dose of 10 AgNP $\mu \mathrm{g} / \mathrm{mL}$, and total inhibition was observed at doses from 25 to $50 \mu \mathrm{g} / \mathrm{mL}$ (Figure 4 ).

AgNP versus $\mathrm{AgNO}_{3}$ Comparison. Data comparison between AgNP and $\mathrm{AgNO}_{3}$ indicated that the latter caused more pronounced effects than those produced by AgNP towards all cell types, that is, cerebral and pulmonary (Figure 5). In particular, in A549 cells, $1 \mu \mathrm{g} / \mathrm{mL}$ of $\mathrm{AgNO}_{3}$ treatment produced a total blockage of the colony formation (i.e., inhibition of cell proliferative activity), while similar amount of AgNP caused 85\% reduction (Figure 5(b)). 


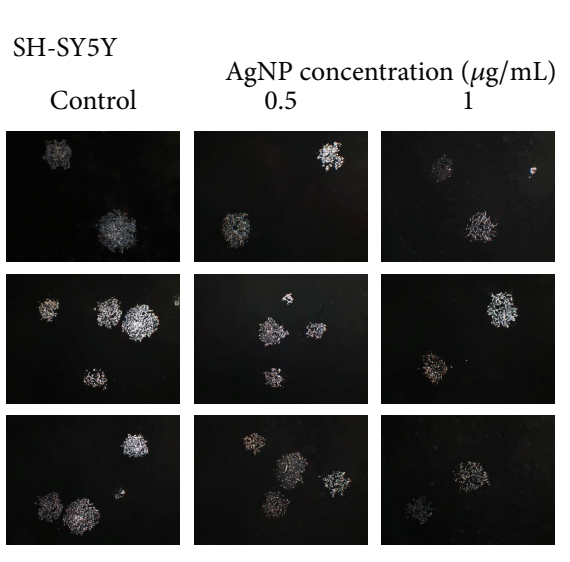

(a)
D384
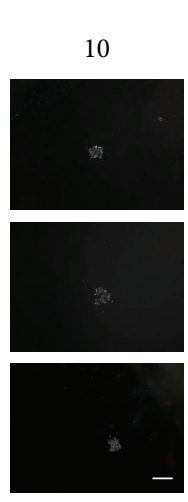

AgNP concentration $(\mu \mathrm{g} / \mathrm{mL})$
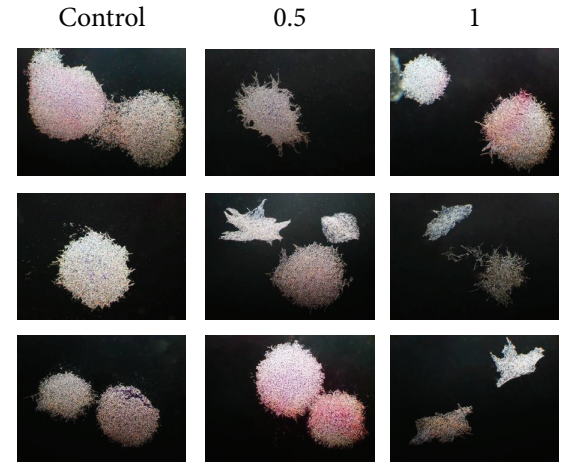
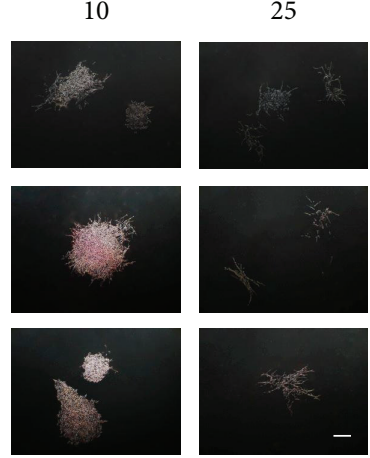

(b)

A549
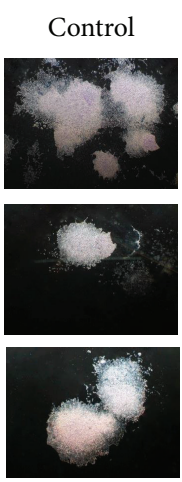

AgNP concentration $(\mu \mathrm{g} / \mathrm{mL})$
0.5
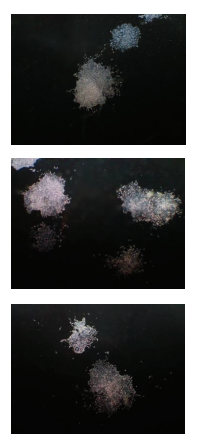

1

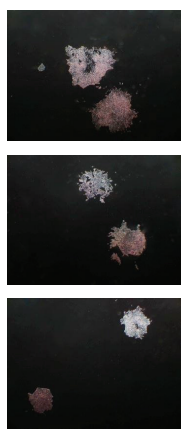

(c)

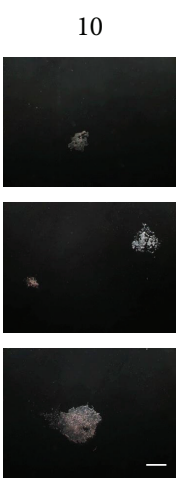

触

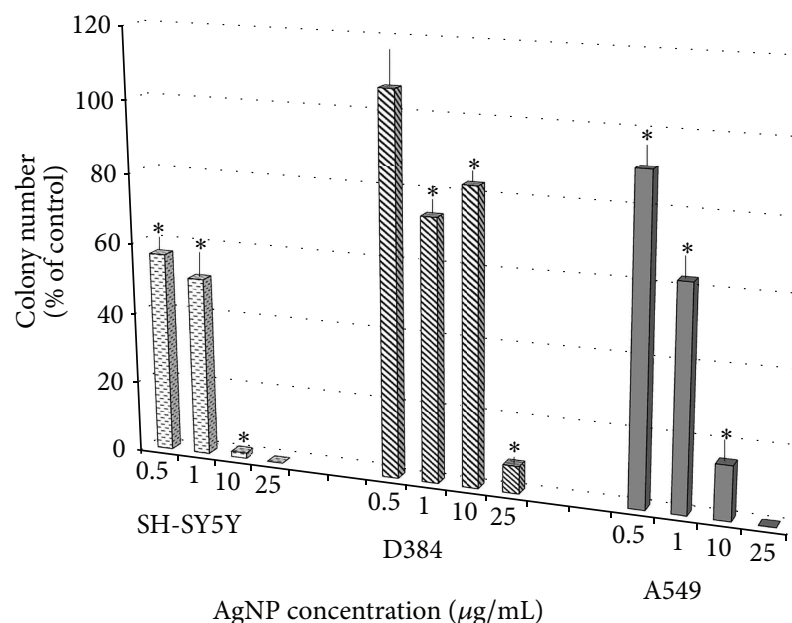

(d)

FIgURE 4: Clonogenic assay up to 10-day exposure. The images of randomly selected microscopic fields show the colonies of SH-SY5Y (a), D384 (b), and A549 (c) cells formed after 7 or 10 consecutive days of exposure to increasing concentration of AgNPs (0.5-25 $\mu \mathrm{g} / \mathrm{mL})$. The colonies of all cell types treated with AgNPs showed dose-dependent reductions on size, colony number, and changes in colony morphology compared to each respective control (scale bar is $600 \mu \mathrm{m}$ ). Panel (d) shows a semiquantitative analysis in SH-SY5Y, D384, and A549 cell lines: histograms display the number of colonies formed after 7 or 10 consecutive days of exposure to increasing concentration of AgNPs $(0.5-25 \mu \mathrm{g} / \mathrm{mL})$. Dose-dependent inhibition of colony formation from all cell models was observed, in particular cell sensitivity was SHSY5Y > A549 > D384. Decrease in SH-SY5Y and D384 colony number was 50\% and 25\%, respectively, at $1 \mu \mathrm{g} / \mathrm{mL}$, and exposure to even lower AgNP dose, such as $0.5 \mu \mathrm{g} / \mathrm{mL}$, was significantly effective towards SH-SY5Y and pulmonary cells. Data are expressed as percentage of respective control colonies. Error bars are \pm S.D. ${ }^{*}$ Significant decrease of colony number: different from control $(P<0.05)$, statistical analysis by ANOVA followed by Tukey's test.

\section{Discussion}

The present study provides the first cytotoxic evidence that exposure of human cerebral SH-SY5Y and D384 cell lines to AgNPs causes cytotoxic effects not only after shortterm exposure (4-48 h) altering mitochondrial metabolism, membrane integrity, and morphology but also after longterm exposure (up to 10 days), at particularly low doses, compromising growth and cell proliferation.
The major results obtained after short-term exposure (4$48 \mathrm{~h}$ ) indicate that:

(i) AgNP treatment produced dose- and time-dependent neurotoxic effects, as indicated by changes in mitochondrial metabolism and damage to the cell membrane, on cerebral cell lines (SH-SY5Y and D384) starting at the dose of $25 \mu \mathrm{g} / \mathrm{mL}$ and after $4 \mathrm{~h}$ exposure. $\mathrm{EC}_{50}$ values were $40.7 \pm 2.0$ and $49.5 \pm 2.1 \mu \mathrm{g} / \mathrm{mL}$ 


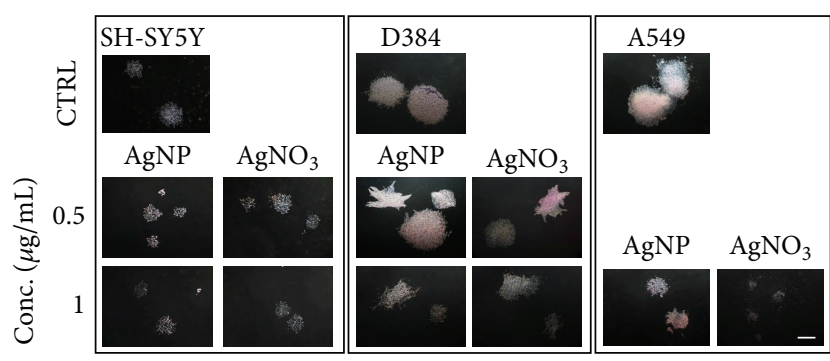

(a)

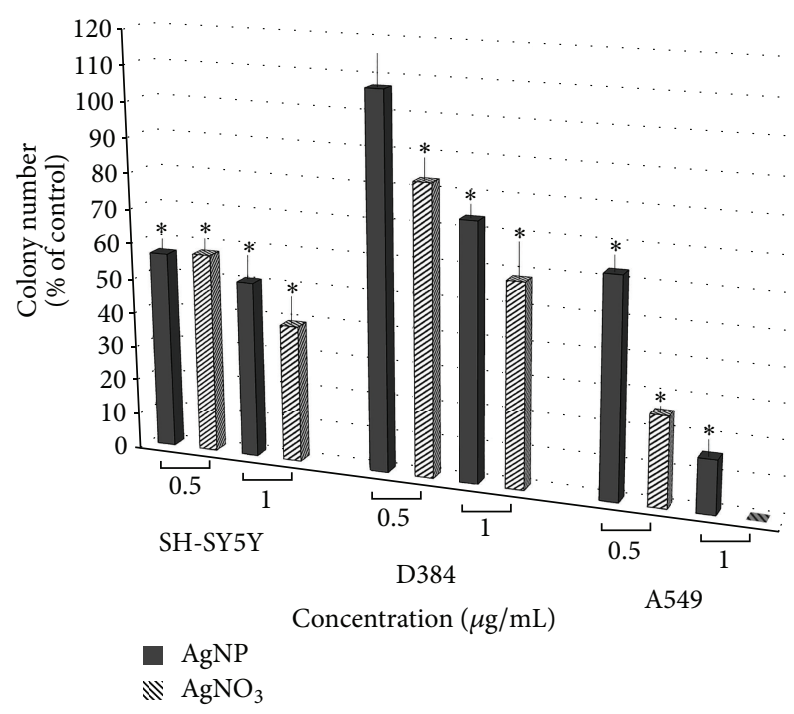

(b)

Figure 5: Data comparison between AgNPs and $\mathrm{AgNO}_{3}$ in $\mathrm{SH}-$ SY5Y, D384, and A549 cells for clonogenic assay. Panel (a) shows images of selected microscopic fields from control and treated cells with AgNPs or $\mathrm{AgNO}_{3}$ at 0.5 and $1 \mu \mathrm{g} / \mathrm{mL}$ for up to 10 days (scale bar is $600 \mu \mathrm{m}$ ). Panel (b) shows the respective semiquantitative analysis for the colony number of SH-SY5Y, D384, and A549 after AgNPs or $\mathrm{AgNO}_{3}$ treatment. $\mathrm{AgNO}_{3}$ induced a more pronounced effect on growth and cell proliferation than AgNP treatment regardless of cell model type. ${ }^{*}$ Different from control in cell line $P<0.05$, statistical analysis by ANOVA followed by Tukey's test.

for SH-SY5Y and D384, respectively, after $4 \mathrm{~h}$ exposure. Pulmonary cells (A549) were less vulnerable to AgNP exposure compared to cerebral cell types;

(ii) low doses (up to about $18 \mu \mathrm{g} / \mathrm{mL}$ ) of AgNPs did not produce any cytotoxic effect within $48 \mathrm{~h}$;

(iii) the magnitude of effects caused by $\mathrm{AgNO}_{3}$ was more pronounced compared to that produced by comparable amount of AgNPs on cerebral cell lines: at $10 \mu \mathrm{g} / \mathrm{mL}$ AgNPs did not produce cytotoxic effect in all cell types considered differently from $\mathrm{AgNO}_{3}$ that showed to be very toxic. In A549 cells analogous low cytotoxic profile was observed after both treatment types (AgNPs and $\mathrm{AgNO}_{3}$ ).
Data achieved after long-term exposure (up to 10 days) revealed that:

(i) extremely low doses $(\leq 1 \mu \mathrm{g} / \mathrm{mL})$ of AgNPs were critical for cell viability since they were able to compromise the proliferative capacity. The effect was evident regardless of cell model type; cell sensitivity was $\mathrm{SH}$ SY5Y > A549 > D384. Decrease in SH-SY5Y and D384 colony number was $50 \%$ and $25 \%$, respectively, at $1 \mu \mathrm{g} / \mathrm{mL}$, and exposure to even lower AgNP dose, such as $0.5 \mu \mathrm{g} / \mathrm{mL}$, was significantly effective towards SH-SY5Y and pulmonary cells;

(ii) different from what was observed in short-term exposure experiments, A549 cells were very sensitive towards a prolonged exposure to AgNPs: $10 \mu \mathrm{g} / \mathrm{mL}$ caused $75 \%$ colony number decrease and $\geq 25 \mu \mathrm{g} / \mathrm{mL}$ suppressed cell growth;

(iii) $\mathrm{AgNO}_{3}$ induced a more pronounced effect on growth and cell proliferation than AgNP treatment.

Regarding the AgNP short-term exposure (4-48 h), we used viability assays (namely, MTT test and Calcein-AM/PI), vital steps in toxicology that explain the cellular response to a toxicant. They give information on cell death, survival, and metabolic activities. The mitochondrial damage is indicated by the reduced dehydrogenase activity as measured by the reduction of tetrazolium dye (MTT), which takes place at the ubiquinone and cytochrome $\mathrm{b}$ and $\mathrm{c}$ sites of the mitochondrial electron transport chain [37]. Membrane integrity is indicated by intracellular esterases activity, while cells with cell membrane damaged are detected by propidium iodide intercalating between the bases of nucleic acids. Simultaneously both live and death cells are marked; the damage in the cell membrane indicates that more cell population is possibly dying by either necrotic or apoptotic pathway.

Our data using these endpoints clearly indicate that no alteration can be detected up to $18 \mu \mathrm{g} / \mathrm{mL}$ in all cell types (cerebral and pulmonary). With respect to the cerebral cell lines, these results are in accordance with data of Luther et al. [23] showing that acute exposure (4h) of primary astrocytes to AgNPs (1-100 $\mu \mathrm{M}$ corresponding to about 1.78$10.78 \mu \mathrm{g} / \mathrm{mL}$ ) did not compromise cell viability despite leading to a concentration-dependent increase in the specific cellular silver content to up to $46 \mathrm{nmol} / \mathrm{mg}$ protein. During a subsequent incubation of the cells in AgNP-free medium, the cellular silver content of AgNP-treated astrocytes remained almost constant for up to 7 days, but the cellular presence of AgNP did neither induce any delayed cell toxicity nor compromise basal metabolism. Nevertheless, AgNP-treated astrocytes strongly upregulated the expression of metallothioneins which (as suggested by the authors) could have helped prevent silver-mediated toxicity induced by possibly AgNP derived silver ions.

In acute $(24 \mathrm{~h})$ experiments, using mixed rat primary neuronal cell cultures (astrocytes and neurons) exposed to AgNP 5-10 $\mu \mathrm{g} / \mathrm{mL}$, a significant cytotoxic effect was observed at $10 \mu \mathrm{g} / \mathrm{mL}$ as well as grossly morphological disorganization of the astrocytes but not neurons, and this seems consistently with the finding that AgNPs were mainly taken up by 
astrocytes and not by neurons. At higher concentration such as $20 \mu \mathrm{g} / \mathrm{mL}$ AgNPs, both cell types exhibited an equally affected morphology [26].

Other experiments conducted with 20-40 nm AgNPs (1$100 \mu \mathrm{g} / \mathrm{mL}$ ) to examine the potential hazardous effects of AgNPs with rat primary neuronal cells demonstrated that AgNPs inhibited neuronal sodium and potassium currents at $10 \mu \mathrm{g} / \mathrm{mL}$, disturbed neuronal calcium homeostasis at $5 \mu \mathrm{g} / \mathrm{mL}$, and reduced dopamine concentration at $50 \mu \mathrm{g} / \mathrm{mL}$ $[24,25]$. On the other hand, up to now, effects due to acute exposure to a noncytotoxic AgNP doses, such as $<0.5 \mu \mathrm{g} / \mathrm{mL}$, were observed only in human epathoma cells (HepG2) in which induced gene expression associated with the cycle progression and apoptosis was reported [38].

The present study clearly demonstrated that cerebral cells (SH-SY5Y and D384) were more vulnerable (effects at concentrations $>10 \mu \mathrm{g} / \mathrm{mL}$ AgNPs) than A549 cells in all the short-term cytotoxicity assays; the toxic effects in A549 are evident only $48 \mathrm{~h}$ after exposure to the highest dosages (50$100 \mu \mathrm{g} / \mathrm{mL}$ ). Indeed, a recent study indicated no toxicity for AgNPs (up to $10 \mu \mathrm{g} / \mathrm{mL}$ of silver) on A549 cells although a high cellular uptake was demonstrated. This lack of toxicity was suggested to be most likely due to low intracellular release of silver ions from AgNPs within short-time periods (424 h) [39]. Silver ions seemed to be toxic via extracellular mechanisms causing cell membrane damage; hypothesis based on the evidence that silver ions dissolved from $\mathrm{AgNO}_{3}$ (with a relatively low cellular penetration capacity) induced much more cell death in terms of loss in cell membrane integrity compared to the exposure to AgNP that did not cause any effect despite its high cellular uptake and high dosage of silver.

The present results obtained after long-term treatment with AgNP suggest that continuous exposure to low AgNP doses $(\leq 1 \mu \mathrm{g} / \mathrm{mL})$ severely affected proliferation of all cell types (SH-SY5Y, D384, and A549).

We used clonogenic test, a noncolorimetric assay, to determine the proliferation ability of all cell types upon longterm exposure to AgNPs. Clonogenic assay is a cell survival assay using the ability of cells to form colonies when seeded at very low cellular concentrations; it identifies the cells that are destined to die or survive. Studies using the clonogenic assay to evaluate cell survival after exposure to nanomaterials are very limited. However, it has been found that this assay was suitable for testing the toxicity of carbon nanotubes [40, 41].

Recently, concentration-dependent effects on the proliferation ability of RBE4 cells (microvascular endothelial cells important for proper function of BBB) exposed to differentsized $(10,50$, and $100 \mathrm{~nm})$ citrate-coated AgNPs for up to 5 days were observed; the colony number was reduced after exposure to 0.01 and $0.1 \mu \mathrm{g} / \mathrm{mL}$ AgNPs $(10 \mathrm{~nm})$ and was totally suppressed at $5 \mu \mathrm{g} / \mathrm{mL}$ [42].

Few data on cultured neurons [27] other than ours indicate that AgNP induces toxicity in cerebral cells at remarkably low doses of $0.5-1 \mu \mathrm{g} / \mathrm{mL}$ in conditions of prolonged AgNP presence. In particular, cultured rat cortical neurons exposed to $1 \mu \mathrm{g} / \mathrm{mL}$ of AgNPs for 2-3 days exhibited compromised cell morphological integrity, degradation of synaptic proteins, and degeneration of cytoskeletal proteins (beta-tubulin and
F-actin) [27]. Our results indicate that a longer period of exposure (up to 10 days) to AgNP concentrations even below $1 \mu \mathrm{g} / \mathrm{mL}$ (i.e., $0.5 \mu \mathrm{g} / \mathrm{mL}$ ) led to a reduced size and colony number as well as changes in colony morphology in SH-SY5Y and pulmonary cell lines compared to untreated cells. $\mathrm{SH}$ SY5Y cells were apparently more susceptible against AgNP treatment when compared with D384 cells (toxic effect at $0.5 \mu \mathrm{g} / \mathrm{mL}$ for SH-SY5Y and $1 \mu \mathrm{g} / \mathrm{mL}$ for D384). This finding is of special interest due to, on one side, the recognized particular role of astrocytes in several neurodegenerative diseases; being more likely, the cell type initially affected during pathogenesis [43]. On the other hand, astrocytes have a variety of important functions such as supplying of metabolic nutrients to neurons and protecting the brain against oxidative stress and metal toxicity [44-47]. Astrocytes communicate with neurons to enable synapse formation, synaptic transmission, plasticity, and synaptic homeostasis $[48,49]$. The high vulnerability of neurons other than astrocytes observed after long-term exposure to low AgNP doses, as demonstrated here, might thus have fundamental consequences on the proper function of neural networks. In addition, several studies have also reported that the rate of nanoparticle translocation into the brain can be significantly increased under certain pathological conditions, such as infection, meningitis, and systemic inflammation $[10,14]$.

The in vivo relevance of these cell culture data should therefore be addressed to explore the CNS effects in in vivo situation. So far, the few in vivo rodent studies have mostly used high level exposure to AgNPs indicating AgNP-induced significant toxicity to a variety of organs including lung, liver, and brain (see review of [50]) with brain appearing as the most sensitive organ. Increased Ag concentrations in the rat brain and olfactory region (about 1.4 and $1.9 \mathrm{ng} / \mathrm{g}$ wet weight, resp.) immediately and (about 1.2 and $3.1 \mathrm{ng} / \mathrm{g}$, resp.) one day after $6 \mathrm{~h}$ inhalation exposure to $15 \mathrm{~nm}$ AgNPs (cumulative dose of $7.2 \mu \mathrm{g}$ ) were reported [51]. In rats subcutaneously injected with AgNPs $(<100 \mathrm{~nm})$ at $62.8 \mathrm{mg} / \mathrm{kg} \mathrm{bw}$, silver crossed the blood-brain barrier and accumulated in the brain (starting at 2 weeks after exposure with levels of $39 \pm 18 \mathrm{ng} /$ brain) along with other organs. Significantly higher Ag tissue content, than in the control group, was observed from 4 to 24 weeks ( $165 \pm 71$ and $362 \pm 120 \mathrm{ng} /$ brain, resp.) after exposure and increased incidence of astrocyte swelling and neuronal degeneration was reported from 2 to 24 weeks after exposure due to the accumulation of AgNPs [12].

Altogether, these in vivo studies (relevant although with high Ag dosage) along with recent in vitro results, including ours (especially from prolonged exposure to AgNPs), encourage additional research and investigation addressing chronic low-dose AgNP exposure that would be useful to translate a realistic human chronic exposure scenario.

Despite several recent in vitro and in vivo publications on AgNP toxicity, the mechanism of AgNP toxicity remains unclear. The most critical question is whether AgNP toxicity is mechanistically unique to nanoparticulate silver or it is the results of the release of silver ions $\left(\mathrm{Ag}^{+}\right)$, a well-known molecular toxicant, or it is the combination of both.

Actually we did not measure the $\mathrm{Ag}^{+}$cellular uptake and release from NPs. The latter seems to depend on a variety of 
factors, such as particle size, the medium used to disperse the NPs, the temperature, the particles crystallinity, and the surface functionalization $[52,53]$. Several studies suggest that the mechanism of AgNP toxicity is largely explained by $\mathrm{Ag}$ ions $\left(\mathrm{Ag}^{+}\right)$. For example, lack of toxicity was observed when $\mathrm{Ag}^{+}$was complexed by a thiol ligand [54-58] or when AgNP was tested under strictly anaerobic conditions that precluded $\mathrm{Ag}(0)$ oxidation and $\mathrm{Ag}^{+}$release [59]. Genetic analysis also evidenced that AgNP toxicity was mediated by ionic silver release [60]. $\mathrm{Ag}^{+}$may be released into solution or may be sorbed by the AgNPs and delivered locally at high doses to the cell (i.e., the Trojan horse effect) [61, 62]. Other studies suggest that ion release does not explain all toxicity, and some support a role for generation of reactive oxygen species (ROS), which might occur at the surface of AgNPs [17, 63-66] but is not expected to result from silver ion dissolution alone. One study reported that cysteine, a strong $\mathrm{Ag}^{+}$ligand, only partially rescued AgNP toxicity [38], while others found that AgNP cytotoxicity was independent of $\mathrm{Ag}^{+}$concentration and resulted primarily from oxidative stress $[65,67]$.

\section{Conclusion}

This study demonstrates cytotoxic effects of AgNPs. The cerebral cell lines are more susceptible than pulmonary ones after acute exposure, while prolonged exposure to low AgNP doses significantly compromises the proliferative capacity of all cell model types.

The relevance of these results is based on the fact that human lung epithelial cells (A549) are representative for common route of human AgNP exposure (e.g., inhalation) and AgNPs are able to translocate from the site of entry to several secondary organs including the CNS.

These in vitro approaches (several endpoints and shortand long-term exposure) allow high throughput, replicates, and parallel complementary tests, which can explain the molecular response of cells caused by AgNP exposure and help to design focused in vivo realistic studies.

\section{Conflict of Interests}

The authors declare that they have no competing interests.

\section{Acknowledgments}

This work was supported by grants from Italian Ministries of Health, Research and Education, and CARIPLO Foundation (Rif. 2011-2096).

\section{References}

[1] S. Becker, "Nanotechnology in the marketplace: how the nanotechnology industry views risk," Journal of Nanoparticle Research, vol. 15, article 1426, 2013.

[2] Woodrow Wilson International Center for Scholars, "The project on emerging nanotechnologies. Nanoscale silver: no silver lining?" 2011, http://www.nanotechproject.org/inventories/consumer/analysis_draft/.
[3] O. Choi, K. K. Deng, N. J. Kim, L. Ross Jr., R. Y. Surampalli, and Z. Q. Hu, "The inhibitory effects of silver nanoparticles, silver ions, and silver chloride colloids on microbial growth," Water Research, vol. 42, no. 12, pp. 3066-3074, 2008.

[4] J. K. Schluesener and H. J. Schluesener, "Nanosilver: application and novel aspects of toxicology," Archives of Toxicology, vol. 87, no. 4, pp. 569-576, 2013.

[5] K. W. Lem, S. H. Hsu, D. S. Lee et al., "Waste minimization for the safe use of nanosilver in consumer products-its impact on the eco-product design for public health," in Public HealthMethodology, Environmental and Systems Issues, J. Maddock, Ed., chapter 10, InTech, Rijeka, Croatia, 2012.

[6] C. You, C. Han, X. Wang et al., "The progress of silver nanoparticles in the antibacterial mechanism, clinical application and cytotoxicity," Molecular Biology Reports, vol. 39, no. 9, pp. $9193-$ 9201, 2012.

[7] S. F. Hansen and A. Baun, "When enough is enough," Nature Nanotechnology, vol. 7, pp. 409-411, 2012.

[8] T. W. Clarkson, "Metal toxicity in the central nervous system," Environmental Health Perspectives, vol. 75, pp. 59-64, 1987.

[9] D. O. Carpenter, "Effects of metals on the nervous system of humans and animals," International Journal of Occupational Medicine and Environmental Health, vol. 14, no. 3, pp. 209-218, 2001.

[10] N. R. Panyala, E. M. Peña-Méndez, and J. Havel, "Silver or silver nanoparticles: a hazardous threat to the environment and human health?" Journal of Applied Biomedicine, vol. 6, no. 3, pp. 117-129, 2008.

[11] J. Rungby and G. Danscher, "Hypoactivity in silver exposed mice," Acta Pharmacologica et Toxicologica, vol. 55, no. 5, pp. 398-401, 1984.

[12] J. Tang, L. Xiong, S. Wang et al., "Distribution, translocation and accumulation of silver nanoparticles in rats," Journal of Nanoscience and Nanotechnology, vol. 9, no. 8, pp. 4924-4932, 2009.

[13] H. S. Sharma, S. Hussain, J. Schlager, S. F. Ali, and A. Sharma, "Influence of nanoparticles on blood-brain barrier permeability and brain edema formation in rats," Acta Neurochirurgica Supplement, vol. 106, pp. 359-364, 2010.

[14] H. S. Sharma and A. Sharma, "Nanoparticles aggravate heat stress induced cognitive deficits, blood-brain barrier disruption, edema formation and brain pathology," Progress in Brain Research, vol. 162, pp. 245-273, 2007.

[15] M. F. Rahman, J. Wang, T. A. Patterson et al., "Expression of genes related to oxidative stress in the mouse brain after exposure to silver-25 nanoparticles," Toxicology Letters, vol. 187, no. 1, pp. 15-21, 2009.

[16] J. H. Sung, J. H. Ji, J. D. Park et al., "Subchronic inhalation toxicity of silver nanoparticles," Toxicological Sciences, vol. 108, no. 2, pp. 452-461, 2009.

[17] P. V. AshaRani, G. L. K. Mun, M. P. Hande, and S. Valiyaveettil, "Cytotoxicity and genotoxicity of silver nanoparticles in human cells," ACS Nano, vol. 3, no. 2, pp. 279-290, 2009.

[18] P. AshaRani, S. Sethu, H. K. Lim, G. Balaji, S. Valiyaveettil, and M. P. Hande, "Differential regulation of intracellular factors mediating cell cycle, DNA repair and inflammation following exposure to silver nanoparticles in human cells," Genome Integrity, vol. 3, article 1, pp. 1-14, 2012.

[19] S. M. Hussain, A. K. Javorina, A. M. Schrand, H. M. H. M. Duhart, S. F. Ali, and J. J. Schlager, "The interaction of 
manganese nanoparticles with PC-12 cells induces dopamine depletion," Toxicological Sciences, vol. 92, no. 2, pp. 456-463, 2006.

[20] J. Wang, M. F. Rahman, H. M. Duhart et al., "Expression changes of dopaminergic system-related genes in PC12 cells induced by manganese, silver, or copper nanoparticles," NeuroToxicology, vol. 30, no. 6, pp. 926-933, 2009.

[21] N. Hadrup, K. Loeschner, A. Mortensen et al., "The similar neurotoxic effects of nanoparticulate and ionic silver in vivo and in vitro," NeuroToxicology, vol. 33, no. 3, pp. 416-423, 2012.

[22] E. M. Luther, Y. Koehler, J. Diendorf, M. Epple, and R. Dringen, "Accumulation of silver nanoparticles by cultured primary brain astrocytes," Nanotechnology, vol. 22, no. 37, Article ID 375101, 2011.

[23] E. M. Luther, M. M. Schmidt, J. Diendorf, M. Epple, and R. Dringen, "Upregulation of metallothioneins after exposure of cultured primary astrocytes to silver nanoparticles," Neurochemical Research, vol. 37, no. 8, pp. 1639-1648, 2012.

[24] Z. Liu, G. Ren, T. Zhang, and Z. Yang, "Action potential changes associated with the inhibitory effects on voltage-gated sodium current of hippocampal CA1 neurons by silver nanoparticles," Toxicology, vol. 264, no. 3, pp. 179-184, 2009.

[25] Z. Liu, G. Ren, T. Zhang, and Z. Yang, "The inhibitory effects of nano-Ag on voltage-gated potassium currents of hippocampal CA1 neurons," Environmental Toxicology, vol. 26, no. 5, pp. 552558, 2011.

[26] A. Haase, S. Rott, A. Mantion et al., "Effects of silver nanoparticles on primary mixed neural cell cultures: uptake, oxidative stress and acute calcium responses," Toxicological Sciences, vol. 126, no. 2, pp. 457-468, 2012.

[27] F. Xu, C. Piett, S. S. Farkas, M. Qazzaz, and I. S. Naweed, "Silver nanoparticles (AgNPs) cause degeneration of cytoskeleton and disrupt synaptic machinery of cultured cortical neurons," Molecular Brain, vol. 6, article 29, 2013.

[28] J. Tang, L. Xiong, G. Zhou et al., "Silver nanoparticles crossing through and distribution in the blood-brain barrier in vitro," Journal of Nanoscience and Nanotechnology, vol. 10, no. 10, pp. 6313-6317, 2010.

[29] W. J. Trickler, S. M. Lantz, R. C. Murdock et al., "Silver nanoparticle induced blood-brain barrier inflammation and increased permeability in primary rat brain microvessel endothelial cells," Toxicological Sciences, vol. 118, no. 1, pp. 160-170, 2010.

[30] REACH, Regulation (EC) No 1907/2006 of the European Parliament and of the Council of 18 December 2006 concerning the Registration, Evaluation, Authorisation and Restriction of Chemicals (REACH), establishing a European Chemicals Agency, amending Directive 1999/45/EC and repealing Council Regulation (EEC) No 793/93 and Commission Regulation (EC) No $1488 / 94$ as well as Council Directive 76/769/EEC and Commission Directives 91/155/EEC, 93/67/EEC, 93/105/EC and 2000/21/EC.

[31] S. Creton, I. C. Dewhurst, L. K. Earl et al., "Acute toxicity testing of chemicals-opportunities to avoid redundant testing and use alternative approaches," Critical Reviews in Toxicology, vol. 40, no. 1, pp. 50-83, 2010.

[32] T. Hartung, T. Luechtefeld, A. Maertens, and A. Kleensang, "Integrated testing strategies for safety assessments," ALTEX, vol. 30, no. 1, pp. 3-18, 2013.

[33] R. Foldbjerg, D. A. Dang, and H. Autrup, "Cytotoxicity and genotoxicity of silver nanoparticles in the human lung cancer cell line, A549," Archives of Toxicology, vol. 85, no. 7, pp. 743750, 2011.

[34] P. Chairuangkitti, S. Lawanprasert, S. Roytrakul et al., "Silver nanoparticles induce toxicity in A549 cells via ROS-dependent and ROS-independent pathways," Toxicology in Vitro, vol. 27, no. 1, pp. 330-338, 2013.

[35] A. J. Balmforth, S. G. Ball, R. I. Freshney, D. I. Graham, H. B. McNamee, and P. F. Vaughan, "D-1 dopaminergic and $\beta$ adrenergic stimulation of adenylate cyclase in a clone derived from the human astrocytoma cell line G-CCM," Journal of Neurochemistry, vol. 47, no. 3, pp. 715-719, 1986.

[36] U. de Simone, L. Manzo, C. Ferrari, J. Bakeine, C. Locatelli, and T. Coccini, "Short and long-term exposure of CNS cell lines to BPA-f a radiosensitizer for boron neutron capture therapy: safety dose evaluation by a battery of cytotoxicity tests," Neurotoxicology, vol. 35, pp. 84-90, 2013.

[37] T. Mosmann, "Rapid colorimetric assay for cellular growth and survival: application to proliferation and cytotoxicity assays," Journal of Immunological Methods, vol. 65, no. 1-2, pp. 55-63, 1983.

[38] K. Kawata, M. Osawa, and S. Okabe, "In vitro toxicity of silver nanoparticles at noncytotoxic doses to HepG2 human hepatoma cells," Environmental Science and Technology, vol. 43, no. 15, pp. 6046-6051, 2009.

[39] P. Cronholm, H. L. Karlsson, J. Hedberg et al., "Intracellular uptake and toxicity of $\mathrm{Ag}$ and $\mathrm{CuO}$ nanoparticles: a comparison between nanoparticles and their corresponding metal ions," Small, vol. 9, no. 7, pp. 970-982, 2013.

[40] E. Herzog, A. Casey, F. M. Lyng, G. Chambers, H. J. Byrne, and M. Davoren, "A new approach to the toxicity testing of carbonbased nanomaterials-the clonogenic assay," Toxicology Letters, vol. 174, no. 1-3, pp. 49-60, 2007.

[41] K. Gellein, S. Hoel, L. Evje, and T. Syversen, "The colony formation assay as an indicator of carbon nanotube toxicity examined in three cell lines," Nanotoxicology, vol. 3, no. 3, pp. 215-221, 2009.

[42] S. Grosse, L. Evje, and T. Syversen, "Silver nanoparticle-induced cytotoxicity in rat brain endothelial cell culture," Toxicology in Vitro, vol. 27, no. 1, pp. 305-313, 2013.

[43] N. J. Maragakis and J. D. Rothstein, "Mechanisms of disease: astrocytes in neurodegenerative disease," Nature Clinical Practice Neurology, vol. 2, no. 12, pp. 679-689, 2006.

[44] J. Hirrlinger and R. Dringen, "The cytosolic redox state of astrocytes: maintenance, regulation and functional implications for metabolite trafficking," Brain Research Reviews, vol. 63, no. 1-2, pp. 177-188, 2010.

[45] E. Tiffany-Castiglioni, S. Hong, and Y. Qian, "Copper handling by astrocytes: insights into neurodegenerative diseases," International Journal of Developmental Neuroscience, vol. 29, no. 8, pp. 811-818, 2011.

[46] V. Parpura, M. T. Heneka, V. Montana et al., "Glial cells in (patho)physiology," Journal of Neurochemistry, vol. 121, no. 1, pp. 4-27, 2012.

[47] I. F. Scheiber and R. Dringen, "Astrocyte functions in the copper homeostasis of the brain," Neurochemistry International, vol. 62, no. 5, pp. 556-565, 2013.

[48] C. Eroglu and B. A. Barres, "Regulation of synaptic connectivity by glia," Nature, vol. 468, no. 7321, pp. 223-231, 2010.

[49] S. L. Valles, "Astrocytes and the important role in the future research of brain," Journal of Alzheimer's Disease and Parkinsonism, vol. 2, article e127, 2012. 
[50] M. Ahamed, M. S. AlSalhi, and M. K. J. Siddiqui, "Silver nanoparticle applications and human health," Clinica Chimica Acta, vol. 411, no. 23-24, pp. 1841-1848, 2010.

[51] S. Takenaka, E. Karg, C. Roth et al., "Pulmonary and systemic distribution of inhaled ultrafine silver particles in rats," Environmental Health Perspectives, vol. 109, no. 4, pp. 547-551, 2001.

[52] S. Kittler, C. Greulich, J. Diendorf, M. Köller, and M. Epple, "Toxicity of silver nanoparticles increases during storage because of slow dissolution under release of silver ions," Chemistry of Materials, vol. 22, no. 16, pp. 4548-4554, 2010.

[53] J. Dobias and R. Bernier-Latmani, "Silver release from silver nanoparticles in natural waters," Environmental Science and Technology, vol. 47, no. 9, pp. 4140-4146, 2013.

[54] E. Navarro, F. Piccapietra, B. Wagner et al., "Toxicity of silver nanoparticles to Chlamydomonas reinhardtii," Environmental Science and Technology, vol. 42, no. 23, pp. 8959-8964, 2008.

[55] O. Bar-Ilan, R. M. Albrecht, V. E. Fako, and D. Y. Furgeson, "Toxicity assessments of multisized gold and silver nanoparticles in Zebrafish embryos," Small, vol. 5, no. 16, pp. 1897-1910, 2009.

[56] L. Kvitek, M. Vanickova, A. Panacek et al., "Initial study on the toxicity of silver nanoparticles (NPs) against Paramecium caudatum," Journal of Physical Chemistry C, vol. 113, no. 11, pp. 4296-4300, 2009.

[57] A. Miao, K. A. Schwehr, C. Xu et al., "The algal toxicity of silver engineered nanoparticles and detoxification by exopolymeric substances," Environmental Pollution, vol. 157, no. 11, pp. 30343041, 2009.

[58] X. Xia, J. Zeng, B. McDearmon, Y. Zheng, Q. Li, and Y. Xia, "Silver nanocrystals with concave surfaces and their optical and surface-enhanced raman scattering properties," Angewandte Chemie-International Edition, vol. 50, no. 52, pp. 12542-12546, 2011.

[59] Z. Xiu, Q. B. Zhang, H. L. Puppala, V. L. Colvin, and P. J. J. Alvarez, "Negligible particle-specific antibacterial activity of silver nanoparticles," Nano Letters, vol. 12, no. 8, pp. 4271-4275, 2012.

[60] J. N. Meyer, C. A. Lord, X. Y. Yang et al., "Intracellular uptake and associated toxicity of silver nanoparticles in Caenorhabditis elegans," Aquatic Toxicology, vol. 100, no. 2, pp. 140-150, 2010.

[61] N. Lubick, "Nanosilver toxicity: ions, nanoparticles-or both?" Environmental Science and Technology, vol. 42, no. 23, p. 8617, 2008.

[62] E. Park, J. Yi, Y. Kim, K. Choi, and K. Park, "Silver nanoparticles induce cytotoxicity by a Trojan-horse type mechanism," Toxicology in Vitro, vol. 24, no. 3, pp. 872-878, 2010.

[63] C. Carlson, S. M. Hussein, A. M. Schrand et al., "Unique cellular interaction of silver nanoparticles: size-dependent generation of reactive oxygen species," Journal of Physical Chemistry B, vol. 112, no. 43, pp. 13608-13619, 2008.

[64] O. Choi and Z. Q. Hu, "Size dependent and reactive oxygen species related nanosilver toxicity to nitrifying bacteria," Environmental Science and Technology, vol. 42, no. 12, pp. 4583-4588, 2008.

[65] S. Kim, J. E. Choi, J. Choi et al., "Oxidative stress-dependent toxicity of silver nanoparticles in human hepatoma cells," Toxicology in Vitro, vol. 23, no. 6, pp. 1076-1084, 2009.

[66] R. Foldbjerg, P. Olesen, M. Hougaard, D. A. Dang, H. J. Hoffmann, and H. Autrup, "PVP-coated silver nanoparticles and silver ions induce reactive oxygen species, apoptosis and necrosis in THP-1 monocytes," Toxicology Letters, vol. 190, no. 2, pp. 156-162, 2009.

[67] H. J. Eom and J. Choi, "p38 MAPK activation, DNA damage, cell cycle arrest and apoptosis as mechanisms of toxicity of silver nanoparticles in Jurkat T cells," Environmental Science and Technology, vol. 44, no. 21, pp. 8337-8342, 2010. 

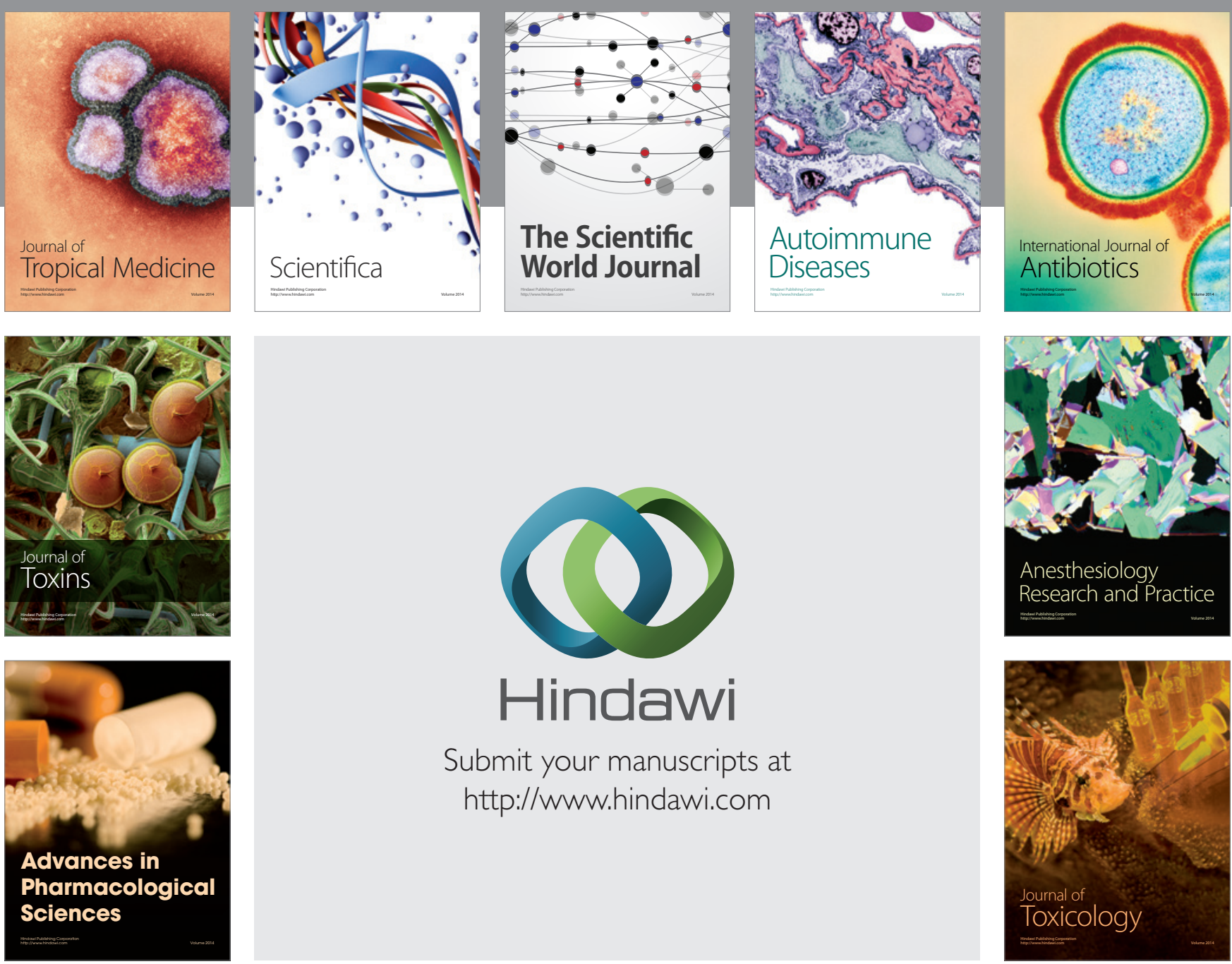

\section{Hindawi}

Submit your manuscripts at

http://www.hindawi.com
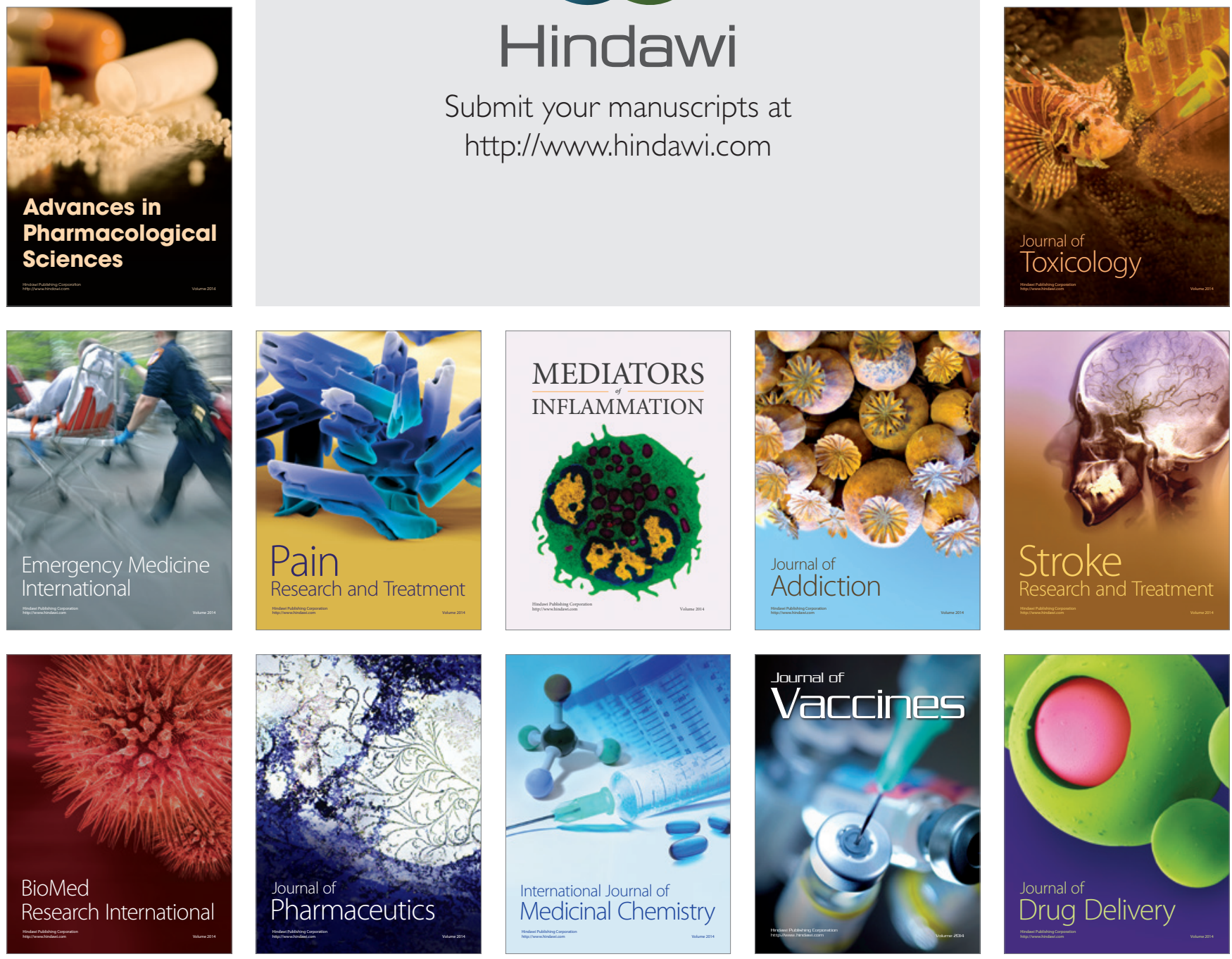